\title{
DYNAMIC LAND USE AND COASTLINE CHANGES IN ACTIVE ESTUARINE REGIONS - A STUDY OF SUNDARBAN DELTA
}

\author{
JV Thomas ${ }^{\mathrm{a} *}$, A Arunachalam ${ }^{\mathrm{a}}$, Rajeev Jaiswal ${ }^{\mathrm{a}}$, PG Diwakar ${ }^{\mathrm{b}}$, B Kiran ${ }^{\mathrm{c}}$ \\ ${ }^{a}$ Earth Observations System, ISRO Headquarters, Bangalore - 560321 - (jvthomas, arunachalam_a, rajeev)@isro.gov.in \\ ${ }^{\mathrm{b}}$ Remote Sensing Applications Area, National Remote Sensing Centre, Hyderabad - 500 037- pgdiwakar@nrsc.gov.in \\ ${ }^{c}$ National Institute of Technology Karnataka (NITK), Surarthkal, Mangalore - 575025 - kiranbpoojar1287@gmail.com
}

KEY WORDS: Climate Change, Sea Level Rise, Remote Sensing, GIS, Shoreline analysis, Vulnerability

\begin{abstract}
:
Alteration of natural environment in the wake of global warming is one of the most serious issues, which is being discussed across the world. Over the last 100 years, global sea level rose by $1.0-2.5 \mathrm{~mm} / \mathrm{y}$. Present estimates of future sea-level rise induced by climate change range from 28 to $98 \mathrm{~cm}$ for the year 2100. It has been estimated that a $1-\mathrm{m}$ rise in sea-level could displace nearly 7 million people from their homes in India. The climate change and associated sea level rise is proclaimed to be a serious threat especially to the low lying coastal areas. Thus, study of long term effects on an estuarine region not only gives opportunity for identifying the vulnerable areas but also gives a clue to the periods where the sea level rise was significant and verifies climate change impact on sea level rise. Multi-temporal remote sensing data and GIS tools are often used to study the pattern of erosion/ accretion in an area and to predict the future coast lines. The present study has been carried out in the Indian Sundarbans area. Major land cover/ land use classes has been delineated and change analysis of the land cover/ land use feature was performed using multi-temporal satellite images (Landsat MSS, TM, ETM+) from 1973 to 2010. Multivariate GIS based analysis was carried out to depict vulnerability and its trend, spatially. Digital Shoreline change analysis also was attempted for two islands, namely, Ghoramara and Sagar Islands using the past 40 years of satellite data and validated with 2012 Resourcesat-2 LISS III data.
\end{abstract}

\section{INTRODUCTION}

Studies have suggested that there is steady increase of the concentration of greenhouse gases in the Earth's atmosphere due to anthropogenic activities, as well as natural reasons. The ultimate result is global warming and climate change. Rising temperature in the atmosphere causes sea level rise and affects low lying coastal areas and deltas of the world. In 1990, Intergovernmental Panel on Climate Change (IPCC) estimates that with a 'business-as-usual' scenario of greenhouse gas emission, the world would be $3.3^{\circ} \mathrm{C}$ warmer by the end of the next century, with a range of uncertainty of 2.2 to $4.9^{\circ} \mathrm{C}$ (Warrick et al., 1993). With rise in temperature, sea level will rise because of thermal expansion and ice melt.

In IPCC Assessment Report 4 (2007), the coastal chapter assessed the impact of climate change and a global sea level rise up to $0.59 \mathrm{~m}$ in 2090s. The coastal systems were considered to be affected mainly by higher sea levels, increasing temperatures, changes in precipitation, larger storm surges and increased ocean acidity. Human activities had continued to increase their pressure on the coasts with rapid urbanization in coastal areas and growth of megacities with consequences on coastal resources. The GMSL (Global Mean Sea Level) rise is projected to be $0.28-0.98 \mathrm{~m}$ by 2100 although with regional variations and local factors the local sea level rise can be higher than the projected for the GMSL. Assessments of coastal impacts, vulnerability and adaptation need to consider relative sea level rise, which includes climate-induced GMSL rise and regional variations as well as local non-climate related sea level changes (IPCC, 2014).

A specific study on Sagar Island of Sundarban area highlighted the threats due to both natural and anthropogenic reasons. The natural reasons include coastal erosion, breach of embankments, loss of landmass and biodiversity, rising sea levels, etc. Besides these, the human interventions also have huge impacts on the vulnerable island ecosystem. Livelihood insecurity of local people, lack of infrastructure like power supply, environmental pollution caused by tourists and degradation caused by other the human activities need immediate attention (Lakshmi and Edward, 2010). Thus, it becomes necessary to study the effect of sea-level rise on the coastal areas.

The coastal environment represents the transition area between land and sea. It is a natural and economic resource of extraordinary value, but is subjected to a continuous and constant transformation. The coastal environment is in fact a highly dynamic system where the erosion (coastline advance or recession) is influenced by several factors, meteorological, geological, biological and anthropogenic (Valerio et al., 2012).

Geomorphology is defined as the study of landforms and landscapes, including the description, classification, origin, development, and history of planetary surfaces. Geomorphology seeks to identify the regularities among landforms and what processes lead to patterns (Kumar et al., 2010). Coastal geomorphology provides a basic understanding of the coastal environment. With the predicted rise in sea level as a result of global warming, there has been increasing speculation and concern as to the impact on coastal geomorphology. The major impacts of sea level rise are changes in coastal wetlands, increased coastal flooding, increased coastal erosion, and saltwater intrusion into estuaries and deltas, which are exacerbated by increased human-induced drivers (IPCC, 2014). The erosion of a sand dune or salt marsh may be part of the internal functioning of the wider coastal system, allowing it to adjust to changes in energy or sediment caused by natural or

\footnotetext{
* Corresponding author.
} 
anthropogenic factors. Alternatively, the progressive loss of coastal landforms such as dunes, marshes or mudflats may be seen as deterioration, in that the resulting system is less capable of responding to imposed changes. The problem facing coastal managers is to be able to distinguish between progressive deterioration and system adjustments to changing inputs (Pethick and Crooks, 2000). Coastal geomorphology is a result of prevailing geomorphic processes that were forced to attain the present morphology. Hence, the geomorphic units are the indicators of the coastal processes that act on it. Coastal erosion and accretion measures changes in shoreline dynamics. Detailed monitoring of these changes is very important, to assess the impact of climate change and sea level rise.

As the climate change and associated sea level rise is proclaimed to be a serious threat to the low lying coastal areas and there are numerous press reports regarding disappearance or increased erosion of islands in the Sundarban islands, a remote sensing based study has been carried out with the basic objectives of understanding the long term changes in the island system, mainly the land use changes and to find out the pattern of erosion/ accretion in the area as well as coast line changes. A study by Jadavpur University observed that total land area of $6402.09 \mathrm{~km}^{2}$ of Indian Sundarbans in the year 2001 has been found to be reduced to $6358.048 \mathrm{~km}^{2}$ in 2009 registering a land net loss of $44.042 \mathrm{~km}^{2}$. This includes erosion of $64.162 \mathrm{~km}^{2}$ and the accretion of $20.120 \mathrm{~km}^{2}$ (Hazra et al., 2010). In this paper, a multivariate GIS based analysis that has been carried out to depict the vulnerability and the trend in the Indian Sundarbans area using multi-temporal satellite data. Further, use of transects for forecasting riverbanks was demonstrated for the Riverbanks of Mekong River in Vietnam (Lam Dao Nguyen, et al., 2010). In this paper, using Digital Shoreline Change Analysis software package (Thieler et al., 2005), an attempt has been made to study the shoreline changes for two islands of Indian Sundarban area, namely Sagar and Ghoramara, over the period of 40 years and prediction of shoreline changes in 2020 has also been attempted.

\section{STUDY AREA}

The Sundarbans are part of the world's largest delta, formed from the sediments brought down by three great rivers, the Ganges, Brahmaputra and Meghna, which converge on the Bengal Basin. The area consists of about 200 islands, separated by some 400 interconnected tidal rivers, creeks and canals. The Sundarbans consists of $10200 \mathrm{~km}^{2}$ of mangrove forest, spread over India and Bangladesh and it is also the largest mangrove forest in the world (http://www.unep-wcmc.org/; www.eoearth.org).

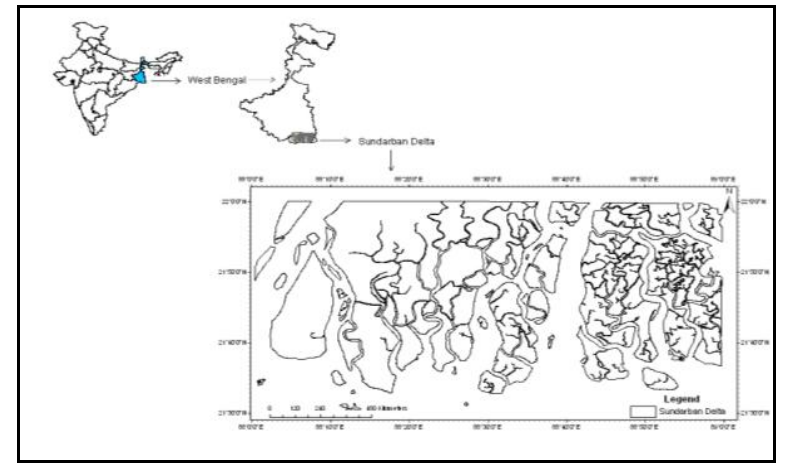

Figure-1: Study Area of Sundarban Delta
The study has been carried out in an area of $5606.36 \mathrm{~km}^{2}$ of the Indian Sundarban area, which is located in West Bengal covering parts of Medinipur and 24 Parganas districts. The study area is shown in Figure-1.

\section{METHODOLOGY}

The overall methodology adopted in this study is shown in Figure-2. The four major steps in this study are (i) Satellite data preparation; (ii) Thematic data generation; (iii) Vulnerability Analysis and (iv) Shoreline Change Analysis

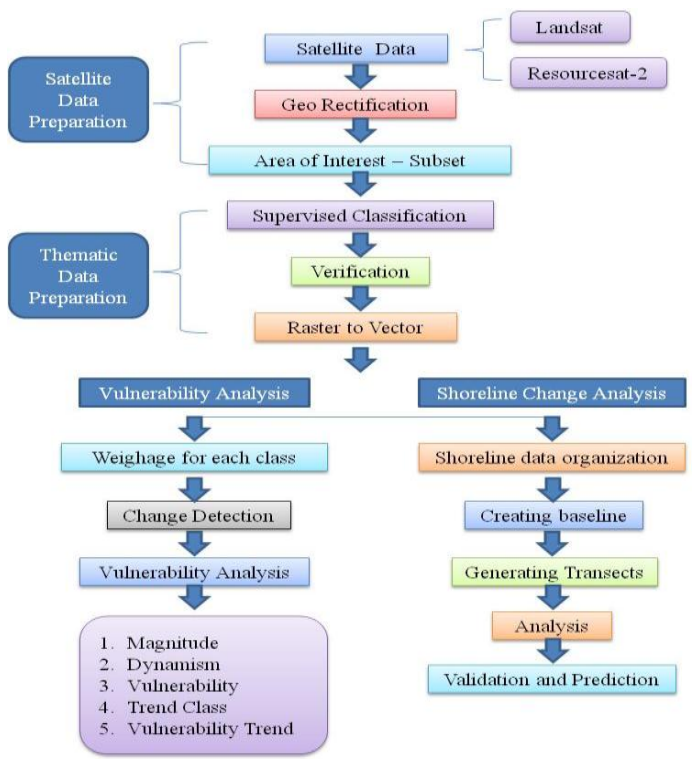

Figure-2: Methodology for GIS based analysis

\subsection{Satellite Data Preparation}

The multi spectral imagery of Landsat MSS, TM, ETM+ and RESOURCESAT-2 - LISS III are used in the study. The multi temporal capabilities of satellite observations allow tracking of changes over time, which is required to meet the objectives of the study. The months are selected in such way to avoid the cloud cover over the study area. All the data used for analysis are of the low tide period. Landsat imagery has been used to track changes (www.earthexplorer.usgs.gov) over the period of about 40 years, i.e., from 1973 to 2010 . RESOURCESAT-2 data of 2012 has been used for validating the model developed for predicting the future shoreline change.

\subsection{Thematic data preparation}

The Land use/ Land cover map using the satellite data was prepared by adopting supervised classification technique. Classified outputs are compared with Google maps as well as field photographs made available by researchers of Indian Institute of Remote Sensing, ISRO. The raster data has been converted to vector data to perform multivariate analysis in vector GIS environment. Weightage was assigned to each of the land use category for further analysis.

\subsection{Weightage Assessment}

Understanding the effect of the sea level rise and resultant subduction of the landmass is an objective of the study, and hence stability of the land class or their susceptibility for subduction is taken as the basis for the assignment of category 
weightage. Accordingly, Agriculture, Fallow land, Mangroves, Sandy Coastal Area and Water are assigned suitable weightages as shown in Table-1.

\begin{tabular}{|c|l|c|}
\hline S. No & \multicolumn{1}{|c|}{ Class Name } & Category Weightage \\
\hline 1 & Agriculture & 1 \\
\hline 2 & Fallow Lands & 2 \\
\hline 3 & Mangrove & 3 \\
\hline 4 & Sandy Coastal Area & 4 \\
\hline 5 & Water & 5 \\
\hline
\end{tabular}

Table-1: Weightage Assignment for each Land use class

The logical reasoning for the weightage assignment is discussed hereunder:

- Agriculture: In the study area, agriculture is prominent in the hinterland region and is considered to be the most stable area. Hence, the agricultural area is assigned a category weightage of 1 . This means that, agricultural area has got least probability of subduction over other classes due to any processes such as sea level rise or the sinking of the islands.

- Fallow Land: In the study area, Fallow land is intermixed with agriculture area. Due to the increase in sea level, the shallow areas in the hinterland are getting inundated due to influx of water through multiple rivulets and the agriculture area is being converted to fallow land. Since these areas are mainly in the hinterland, a category weightage 2 is assigned to them. This means that fallow land has a probability of subduction more than agricultural area but less than that of other classes.

- Mangrove: The mangroves are generally observed in the coastal areas of the inhabited islands. Some of the uninhabited islands are fully covered by mangroves. The Mangrove vegetation develops in the estuaries where sweet river water meets the saline water of the sea. Hence this area is considered to be a fragile area and any sea level change will affect these area and assigned a category weightage of 3 .

- Sandy Coastal Area: The sandy coastal area is the fringe of the islands, which are devoid of any vegetation cover. The sandy coastal areas are very dynamic and keep changing when compared to other classes. Hence these are considered to be the most fragile class and most susceptible to sea level change and assigned a category weightage of 4 .

- Water: In the study area, major portion is water. This class is assigned a category weightage of 5 .

\subsection{Vulnerability Analysis}

Vulnerability can be defined as an internal risk factor of the subject or system that is exposed to a hazard and corresponds to its intrinsic predisposition to be affected, or to be susceptible to damage. Vulnerability may be understood, in general terms, as an internal risk factor that is mathematically expressed as the feasibility that the exposed subject or system may be affected by the phenomenon that characterizes the hazard. Thus, risk is the potential loss to the exposed subject or system resulting from the convolution of hazard and vulnerability. In this sense, risk may be expressed in a mathematical form as the probability of surpassing a determined level of economic, social, or environmental consequence at a certain site and during a certain period (Kumar et al., 2010).
For an area, if the land use category has changed from agriculture (category weightage 1) in 1973 to water (category weightage 5) in 1980, the weightages for those areas are calculated as 4 (5-1) in the Union layer of 1973-80. Similarly an area changing from water to agriculture gets a weightage of -4 (1-5). The absolute value of the weightage indicates the magnitude of change over the period 1973-80. The +/- sign indicates the trend of the change, +ve sign indicates change towards increased vulnerability to submergence of the area and -ve sign indicates that reduced vulnerability.

After calculating weightage for all four resultant layers, all the four layers are again integrated to carryout vulnerability analysis. In the vulnerability analysis various parameters to describe the vulnerability viz., Magnitude, Dynamism, Vulnerability, Trend pattern, and Vulnerability Trend pattern are calculated. For an area, the magnitude is calculated by adding the weightages of the four union layers in the attribute table; Dynamism is calculated by adding the absolute values of the weightages of four layers; Vulnerability is calculated on the basis of both magnitude and dynamism; Trend pattern is calculated based on the direction of land use change; a new index, vulnerability trend, is calculated based on the Trend of the land cover category and Vulnerability.

\subsection{Shoreline change Analysis}

Coastal shorelines are subjected to frequent changes due to coastal processes, which are controlled by wave characteristics and the resultant near shore circulation, sediment characteristics, beach form, etc. The coastline in estuaries such as Sundarban is further affected by riverine processes such as current, flow velocity, erosion, sediment load, etc. The Sundarban islands, made up of clayee sediments, are also subjected to subduction due to the compaction of sediments. From the coastal vulnerability point of view, coasts subjected to accretion will be considered as less vulnerable areas as they move toward the ocean and result in the addition of land areas, whereas areas of coastal erosion will be considered as more vulnerable because of the resultant loss of private and public property and important natural habitats such as beaches, dunes, and marshes.

For the analysis of shoreline, Digital Shoreline Analysis System (DSAS) Version 9.3 Extension for ArcGIS, which enables users to calculate shoreline rate-of-change statistics from a time series of multiple shoreline positions, was downloaded from USGS website and used. The vector Shorelines of multiple years are extracted from the land use maps of each year. The baseline, which is the starting point for all transects, is created by enveloping all the shorelines. The baseline and individual shorelines are provided as input to the model. The DSAS package generates three attribute tables namely, Transect, Intersect and Distance. In this study, Jack-knife Rate (JKR) method was used to predict future shoreline, since it is similar to linear regression but less influenced by the outliers of data clusters. Here in this study, there are only five points and the points are widely spread. Hence JKR was considered as an appropriate method to predict the future coastline point. The object identifier value in the Transect attribute table serves as a link to the Intersect table and the Distance table, where it is called as the Transect ID. This facilitates analysis and organization of the transects and provides users with the intersect point and distance values used in all rate-of-change statistics, as well as providing additional statistical information (Net Shoreline Movement and Shoreline Change Envelope calculations) found in the distance table. 


\section{RESULTS AND DISCUSSION}

The classified images of 1973, 1980, 1989, 2000 and 2010 are shown in Figure-3. It can be observed from the classified images that the islands in the North Western area inhabited and majority of the area are converted to agriculture areas. At the same time, islands in the North Eastern area are still pristine and a heavy growth of mangroves is noticed. The fallow lands are seen mostly in the middle of the Sundarban area in both inhabited and un-inhabited islands and believed to be originated due to ingression of sea water through the rivulets to the low lying areas. The coastal sandy areas are associated with the coastal areas and very dynamically changing due to erosion and other processes.
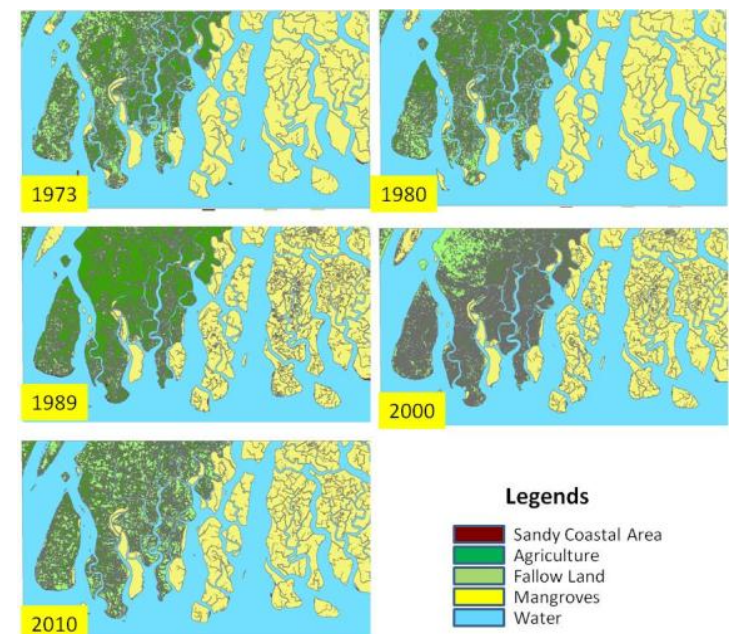

Figure-3: Classified images (a) 1973, (b) 1980, (c) 1989, (d) 2000 and (e) 2010

The sandy coastal area and agriculture was more in 1989, compared to other years. Fallow land has increased from 609 $\mathrm{km}^{2}$ to $677 \mathrm{~km}^{2}$ during the period from 1973 to 2010 . Water level has increased from $2722 \mathrm{~km}^{2}$ to $2781 \mathrm{~km}^{2}$ from 1973 to 2010. It was also observed that the mangrove area has decreased from $1600 \mathrm{~km}^{2}$ to $1518.72 \mathrm{~km}^{2}$, from 1973 to 2010 . The details are given in Table-2.

\begin{tabular}{|c|r|r|r|r|r|}
\hline \multirow{2}{*}{ Class name } & \multicolumn{5}{|c|}{${\text { Area }\left(\mathbf{K m}^{2}\right)}^{\mathbf{2}}$} \\
\cline { 2 - 6 } & $\mathbf{1 9 7 3}$ & $\mathbf{1 9 8 0}$ & $\mathbf{1 9 8 9}$ & $\mathbf{2 0 0 0}$ & $\mathbf{2 0 1 0}$ \\
\hline $\begin{array}{c}\text { Sandy } \\
\text { coastal area }\end{array}$ & 9.10 & 4.73 & 16.06 & 9.526 & 9.50 \\
\hline Agriculture & 664.37 & 691.55 & 1114.86 & 570.19 & 619.71 \\
\hline Fallow land & 609.55 & 562.08 & 281.31 & 770.87 & 677.00 \\
\hline Water & 2722.81 & 2761.00 & 2701.33 & 2725.73 & 2781.42 \\
\hline Mangrove & 1600.53 & 1587.01 & 1492.80 & 1530.05 & 1518.73 \\
\hline
\end{tabular}

Table-2: Area Statistics based on Supervised Classification

\subsection{Vulnerability Analysis}

\subsubsection{Magnitude of land use changes:}

Magnitude of land use change is performed to observe that overall changes happened in the area during the last 40 years and it is shown in Figure-4. The resultant weightage for magnitude class can range from -4 to 4 . This weightages are classified into three groups as shown in Table-3. The class -4 to 0 is called positive change, because the changes indicate that the stability of the area has increased. Whenever the island building happens or the vulnerable classes change to a more stable class, the positive changes happen. The second class is no change class (magnitude 0 ). The third category is the negative change category (magnitude 0 to 4 ), which indicates the stability factor of the area has reduced.

\begin{tabular}{|c|c|c|c|}
\hline S. No & Weightage & $\begin{array}{c}\text { Magnitude } \\
\text { class }\end{array}$ & Category \\
\hline 1 & -4 to 0 & -1 & $\begin{array}{c}\text { Positive } \\
\text { Change }\end{array}$ \\
\hline 2 & 0 & 0 & Normal \\
\hline 3 & 0 to 4 & 1 & $\begin{array}{c}\text { Negative } \\
\text { Change }\end{array}$ \\
\hline
\end{tabular}

Table-3: Magnitude of land use Changes

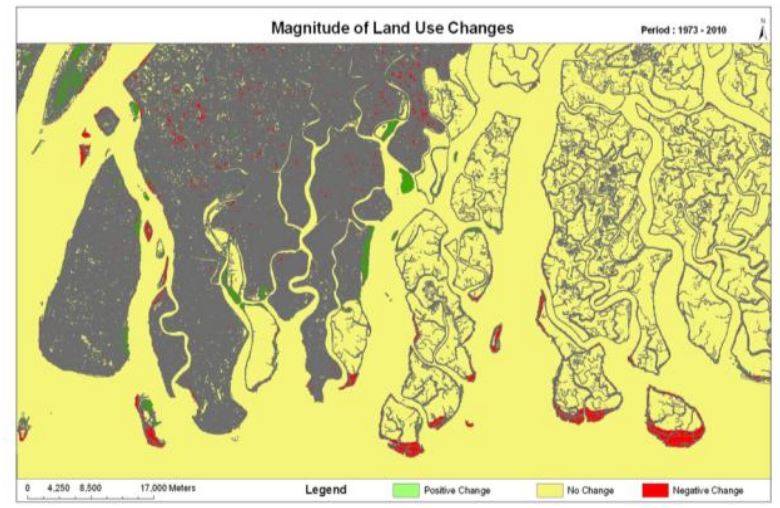

Figure-4: Magnitude of Land use Changes during 1973-2000

\subsubsection{Dynamism of land use changes}

Dynamism indicates how often an area has undergone changes in the land use category. This is computed by comparing every 10 years data by adding the absolute values of weightages of final resultant layer. The resultant weightage for dynamism classes can vary between 0 to 16 and this has been grouped into 4 classes as shown in Table-4. Weightage of 1 to dynamism represent normal, 2 represent mildly dynamic, 3 represents very dynamic and 4 represents extremely dynamic classes.

\begin{tabular}{|c|c|c|c|}
\hline S.No & Weightage & $\begin{array}{c}\text { Dynamism } \\
\text { Class }\end{array}$ & Category \\
\hline 1 & $0-4$ & 1 & Normal \\
\hline 2 & $4-8$ & 2 & $\begin{array}{c}\text { Mildly } \\
\text { Dynamic }\end{array}$ \\
\hline 3 & $8-12$ & 3 & $\begin{array}{c}\text { Very } \\
\text { Dynamic }\end{array}$ \\
\hline 4 & $12-16$ & 4 & $\begin{array}{c}\text { Extremely } \\
\text { Dynamic }\end{array}$ \\
\hline
\end{tabular}

Table-4: Dynamism of land use Changes

As the name indicates, the normal class (Class 1) has remained unchanged or with minor changes in the last 40 years under study. The very dynamic and extremely dynamic categories (Class 3 and 4) have undergone severe changes in each of the decadal period. The Dynamism map, as shown in Figure-5, portrays the areas which are very susceptible to the changes in the study area. 


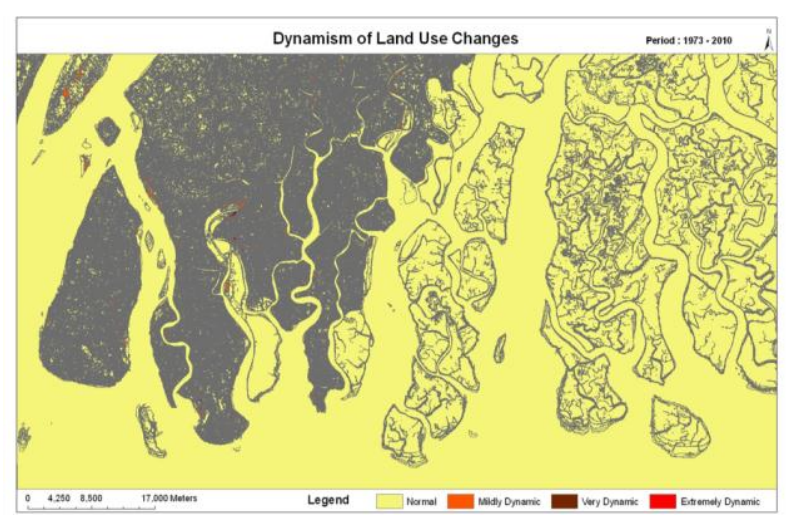

Figure-5: Dynamism of Land use Changes during 1973-2000

\subsubsection{Vulnerability analysis of land use changes}

Vulnerability was calculated on the basis of both magnitude and dynamism. This takes into account the magnitude i.e., whether it is a positive change or negative change and the dynamism of the area, i.e., how fast the changes are happening. Based on this, seven classes are identified, which vary from very good to extremely severe as shown in Table-5. The good category means that there are land building processes and changes are happening at a faster pace. The severe categories are those which loose land to water or tending towards submergence and proportional to the value of dynamism it increases the severity. Figure- 6 shows the vulnerable areas in different severity order. As can be seen from the map, Dalhousie, Bhangaduni, Bulchery, Jambudwip Islands have vulnerable areas.

\begin{tabular}{|c|c|c|c|c|}
\hline S.No & Magnitude & Dynamism & Category & $\begin{array}{l}\text { Vulner } \\
\text {-ability }\end{array}$ \\
\hline 1 & \multirow{3}{*}{-1} & 4 & Very Good & 1 \\
\hline 2 & & 3 & Good & 2 \\
\hline 3 & & 1,2 & Normal & \multirow{2}{*}{3} \\
\hline 4 & \multirow{3}{*}{0} & 1,2 & Normal & \\
\hline 5 & & 3 & Mild & 4 \\
\hline 6 & & 4 & Severe & \multirow{2}{*}{5} \\
\hline 7 & \multirow{3}{*}{1} & 1,2 & Severe & \\
\hline 8 & & 3 & $\begin{array}{l}\text { Very } \\
\text { Severe }\end{array}$ & 6 \\
\hline 9 & & 4 & $\begin{array}{l}\text { Extremely } \\
\text { Severe }\end{array}$ & 7 \\
\hline
\end{tabular}

Table-5: Vulnerability Analysis of land use Changes

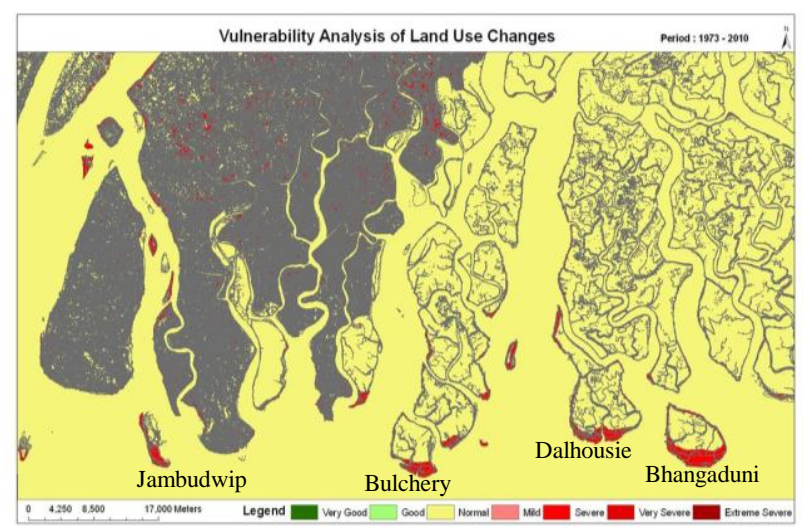

Figure-6: Vulnerabity Analysis of Land use Changes

\subsubsection{Trend pattern of land use changes}

As explained earlier, the changes in the land use pattern are observed in each decadal time frame and capturing the trend of change is important to identify the most vulnerable areas which are threatened by submergence due to the active processes in the region. It is derived based on the trend of the land cover category over the period of 40 years, i.e., whether the particular area is moving from land towards water (negative change), water towards land (positive change) or remains unchanged. Based on the trend of land category, the pattern has been analysed. The classes are given in Table- 6 and the map is shown in Figure-7.

\begin{tabular}{|c|c|c|c|}
\hline S.No. & Condition & $\begin{array}{l}\text { Trend } \\
\text { Code }\end{array}$ & Category \\
\hline 1 & $\begin{array}{l}\text { Category weight of } 73 \text { or } \\
80<=3 \text {, } \\
\text { And Category weight of } \\
89 \text { or } 00 \text { or } 10>3\end{array}$ & D1 & \multirow{3}{*}{$\begin{array}{l}\text { Negative } \\
\text { change }\end{array}$} \\
\hline 2 & $\begin{array}{l}\text { Category weight of } 73 \text { or } \\
80<=3 \text {, } \\
\text { And Category weight of } \\
89 \& 00 \& 10>3\end{array}$ & D2 & \\
\hline 3 & $\begin{array}{l}\text { Category weight of } 73 \text { or } \\
80<=3 \text {, } \\
\text { And Category weight of } \\
89=00=10>3\end{array}$ & D3 & \\
\hline 4 & $\begin{array}{l}\text { Category weight of } 73 \text { or } \\
80>=4, \\
\text { And Category weight of } \\
89 \text { or } 00 \text { or } 10<3\end{array}$ & B1 & \multirow{3}{*}{$\begin{array}{l}\text { Positive } \\
\text { change }\end{array}$} \\
\hline 5 & $\begin{array}{l}\text { Category weight of } 73 \text { or } \\
80>=4 \text {, } \\
\text { And Category weight of } \\
89 \& 00 \& 10<3\end{array}$ & B2 & \\
\hline 6 & $\begin{array}{l}\text { Category weight of } 73 \text { or } \\
80>=4 \text {, } \\
\text { And Category weight of } \\
89=00=10<3\end{array}$ & B3 & \\
\hline 7 & $\begin{array}{l}\text { Category weight of } 73= \\
80=89=00=10\end{array}$ & $\mathrm{~N}$ & Normal \\
\hline
\end{tabular}

Table-6: Trend pattern of land use changes

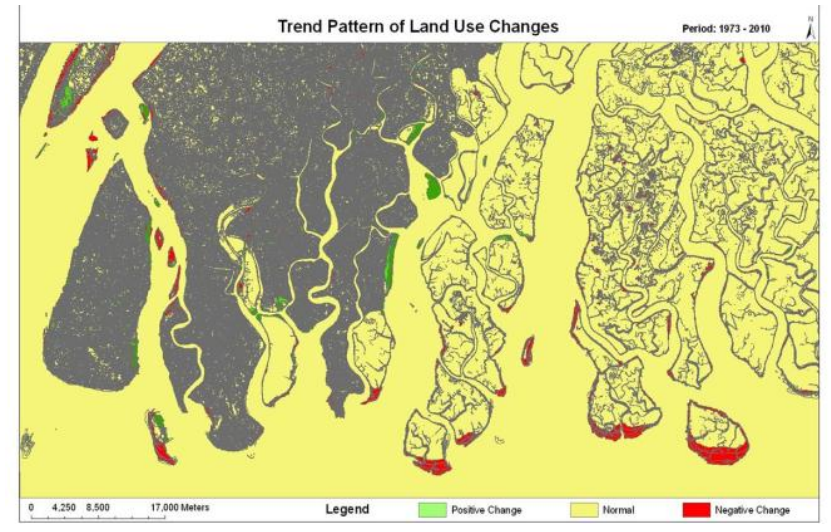

Figure-7: Trend Pattern of Land Use Changes

Based on the Trend of the land cover category and vulnerability, a new index, vulnerability trend, has been derived. It takes into account both Vulnerability as well as the Trend. This map 
shows the overall vulnerability. Figure-8 shows the vulnerability trend map of the Sundarban area.

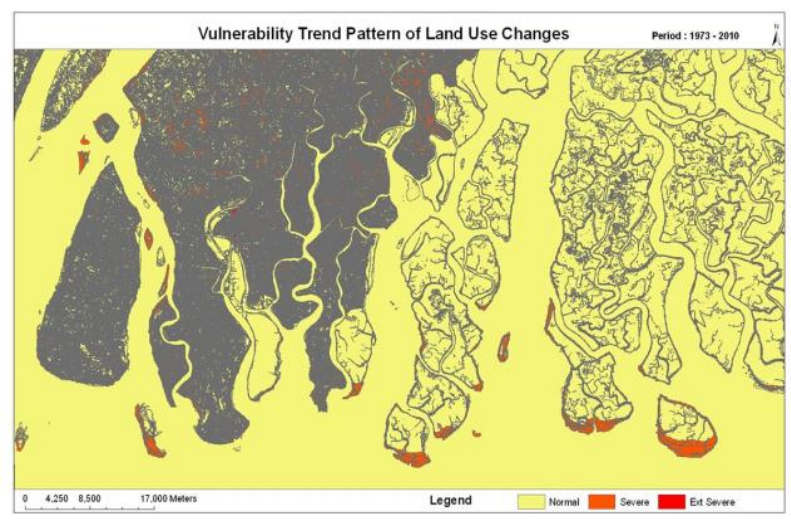

Figure-8: Vulnerability Trend Pattern of Land Use Changes

In order to understand the submergence rate, area of a few islands viz., Ghoramara, Jambudwip, Bulchery, Bhangaduni and Dalhousie have also been analysed. These islands are submerging at a faster rate. The area was calculated for each of these islands is given in Table-7. As can be seen from the table, Bhagaduni and Dalhousie have lost more than $15 \mathrm{~km}^{2}$ area over a period of 40 years.

\begin{tabular}{|c|c|c|c|c|c|}
\hline Islands & $\begin{array}{c}\text { Ghora } \\
\text { mara }\end{array}$ & $\begin{array}{c}\text { Jumbu } \\
\text { dwip }\end{array}$ & $\begin{array}{c}\text { Bulch } \\
\text { ery }\end{array}$ & $\begin{array}{c}\text { Dalho } \\
\text { usie }\end{array}$ & $\begin{array}{c}\text { Bhanga } \\
\text { duni }\end{array}$ \\
\hline $\mathbf{1 9 7 3}$ & 7.734 & 8.266 & 29.911 & 79.265 & 43.01 \\
\hline $\mathbf{1 9 8 0}$ & 6.717 & 7.033 & 28.774 & 76.798 & 40.636 \\
\hline $\mathbf{1 9 8 9}$ & 6.124 & 6.913 & 27.796 & 70.65 & 36.579 \\
\hline $\mathbf{2 0 0 0}$ & 5.34 & 5.08 & 24.015 & 67.586 & 31.551 \\
\hline $\mathbf{2 0 1 0}$ & 4.076 & 4.617 & 22.139 & 63.026 & 25.954 \\
\hline $\begin{array}{c}\text { Net Loss } \\
-\mathbf{1 9 7 3} \text { to } \\
\mathbf{2 0 1 0}\end{array}$ & 3.658 & 3.649 & 7.772 & 16.239 & 17.056 \\
\hline
\end{tabular}

Table-7: Estimation of land loss of the southern most vulnerable islands in Indian Sundarban (area in $\mathrm{km}^{2}$ )

\subsection{Shoreline change modelling}

There are various models in practice to model the shoreline changes that can be utilised to predict the future shorelines. The process based modelling gives better results since they take care of the various processes acting in each region. In this study, it is assumed that the processes acting in the area are constant and based on the changes observed in the past an effort is made to predict the future coastline. Since the macro scale processes are different in each segment, the coastline is divided into numerous short segments and statistical methods are used to predict the next point for each of these segments. As discussed in the methodology, digital shoreline analysis was conducted for two of the islands viz., Ghoramara and Sagar Islands, to know how shorelines changes due to sea level rise in the 40 years and also predicting the future shoreline using previous shorelines. Validation of the predicted shoreline was carried out using the remote sensing data of the year 2012.

Figures 9 and 10 shows the shoreline changes, validation carried out for 2012 and the predictions for 2020 for Ghoramara and Sagar Islands respectively. In these figures, red dots (marked as G-2020 events) show the predicted shoreline points for 2020. For the validation, coastline for 2012 was predicted using the earlier coastlines (marked as G-12 events) and validated with the coastline derived from Resourcesat-2 data.
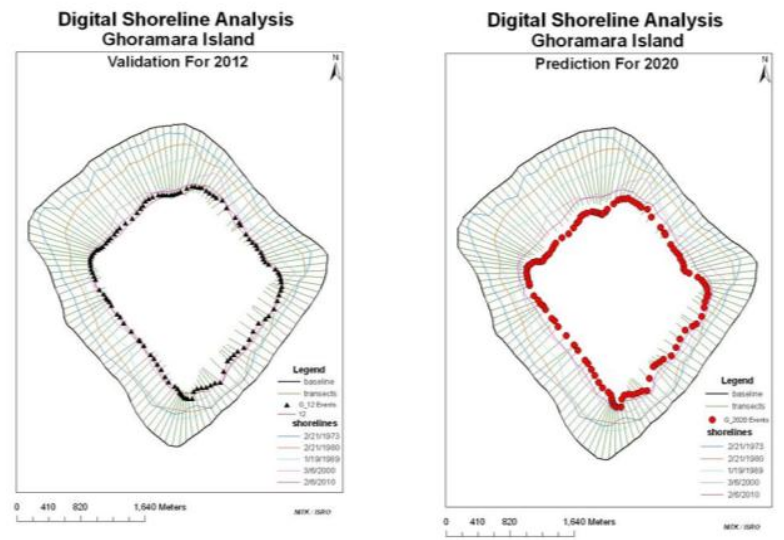

Figure-9: Shoreline Change Analysis of Ghoramara Island
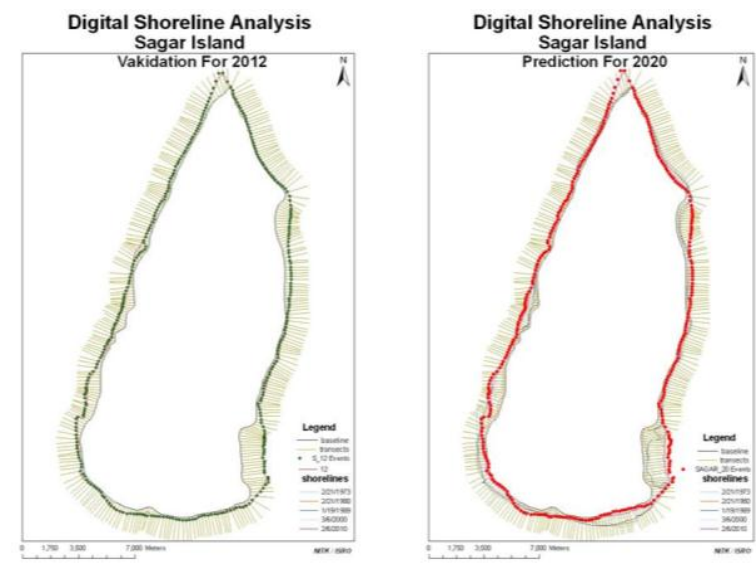

Figure-10: Shoreline Change Analysis of Sagar Island

The validation shows that the predicted coastline very closely matches with the actual coastlines. Such statistical modelling of coastlines gives better results for coastlines where the number of active processes is limited and generally follows a uniform trend.

\section{CONCLUSION}

Remote Sensing and GIS are efficient tools to monitor the dynamism of land cover categories. Based on the analysis of satellite data over 40 years in the Sundarban Estuary, it is observed that land areas were increasing from 1973 to 1989 and decreasing then onwards. This implies that subduction of area is happening since 1989. However, reasons for subduction need to be analyzed. Based on analysis, it can be stated that not all islands are disappearing. Some islands, which disappeared in 2000, have reappeared in 2010. It indicates that at some places erosion happens and at the same time deposition happens at other places, which are captured and depicted in the study. Multivariate GIS based analysis was carried out to depict the vulnerability and the vulnerability trend spatially. In addition to sea level changes, river actions are also causing erosion in the 
active channel areas. Vulnerability analysis shows that Sagar, Ghoramara, Jambudwip, Bulchery, Bhangaduni and Dalhousie are highly vulnerable to submergence. Prediction of shore line change was attempted for Ghoramara and Sagar island using the past 40 years data. The model yields very good results and are also validated with 2012 data and the predicated lines closely matches the actual coast lines.

Based only on the increased erosion or disappearance of certain unstable landmass (islands), one cannot establish that it is due to climate change related sea level rise. To establish the cause of the increased erosion or submergence of lands, an in depth study of the region with in-situ data is required. The river flow data, sediment load brought to the sea, tidal gauge data, analysis of the compaction of the sediments, wave actions, coastal currents and the sea level rise data are some of the important parameters, which would identify the causative factor for the disappearance or sinking of the islands. The statistical method, as adopted in this study, assumes that the processes acting on the region are constant throughout the last 40 years and assumes they continue to do so. Hence, a process based study using in-situ data will complement the remote sensing based analysis and modelling.

\section{ACKNOWLEDGEMENTS}

Authors would like to thank Indian Institute of Remote Sensing, Dehradun for sharing the ground truth photographs. Authors would also like to thank USGS and NRSC/ ISRO for the Satellite Imagery. Authors would also like to thank National Institute of Technology Karnataka, Surathkal for their support.

\section{REFERENCES}

Asta Lakshmi, S., and Patterson Edward, J.K., 2010. Coastal issues and management strategy for Sagar Island in Bay of Bengal, Recent Research in Science and Technology, 2(5): 96101, http://www.recent-science.com (accessed Sept 25, 2014)

IPCC (Intergovernmental Panel on Climate Change). 2001. IPCC Report, Working Group-I, Climate Change-2001: The Scientific Basis. Cambridge, UK: Cambridge University Press. http://www.ipcc.ch/ipccreports/tar/wg1/408.htm (accessed April 10, 2007).

IPCC (Intergovernmental Panel on Climate Change), Fifth Assessment Report. Final Draft, Working Group-II, Chapter 5, http://www.ipcc.ch/report/ar5/index.shtml (accessed Sept 25, 2014)

John S. Pethick and Stephen Crooks, 2000. Development of a coastal vulnerability index: a geomorphological perspective, Environmental Conservation 27 (4): 359-367, http://portal.nceas.ucsb.edu/

Lam Dao Nguyen, Nguyen Thanh Minh, Pham Thi Mai Thy, Hoang Phi Phung and Hoang Van Huan., 2010. Analysis of changes in the riverbanks of Mekong river - Vietnam by using Multi-Temporal Remote Sensing Data, International Archives of the Photogrammetry, Remote Sensing and Spatial Information Science, Kyoto Japan 2010, Volume XXXVIII, Part 8, pp. 287-292.
Srinivasa Kumar, T., Mahendra, R.S., Shailesh Nayak, Radhakrishnan, K., and Sahu1, K.C., 2010. Coastal Vulnerability Assessment for Orissa State, East Coast of India, Journal of Coastal Research, Vol. 26, No. 3, 2010. pp. 523-534. http://indiaenvironmentportal.org.in/files/Coast\%20Orissa.pdf (accessed Sept 28, 2014)

Sugata Hazra, Kaberi Samanta, Anirban Mukhopadhyay and Anirban Akhand., 2010. "Temporal Change Detection (20012008) Study of Sundarban". www.iczmpwb.org/main/pdf/ ebooks/WF_FinalReportPDF.pdf (accessed Sept 28, 2014)

Thieler, E.R., Himmelstoss, E.A., Zichichi, J.L., and Miller, T.L., 2005. Digital Shoreline Analysis System (DSAS) version 3.0; An ArcGIS $\odot$ extension for calculating shoreline change: U.S. Geological Survey Open-File Report 2005-1304. http://woodshole.er.usgs.gov/project-pages/dsas/version3/ images/pdf/DSASv3_2.pdf

Valerio Baiocchi, Raffaella Brigante, Donatella Dominici, Fabio Radicioni., 2012. Coastline Detection Using High Resolution Multispectral Satellite Images, https://www.fig.net/pub/fig2012/papers/ts06i/TS06I_baiocchi_b rigante_et_al_6008.pdf (accessed Sept 25, 2014)

Warrick. R.A., Bhuiya. A.H., Mirza. M.Q.. 1993. "Climate Change and Sea-level Rise: the Case of the Coast", Briefing Document No. 6, Bangladesh Unnayan Parishad (BUP), Dhaka.

http://www.unep-wcmc.org/ accessed on Sept 19, 2011

http://www.eoearth.org/ accessed on Sept 28, 2014

http://www.earthexplorer.usgs.gov for Landsat imagery 